\title{
CANVAS BUSINESS MODEL ESTABLISHED BY THE BALI PETRO JAYA COMPANY DURING COVID-19
}

\author{
${ }^{a}$ Gusi Putu Lestara Permana, 'b Made Garin Andana \\ a,b Universitas Pendidikan Nasional \\ lestarapermana@undiknas.ac.id
}

\begin{tabular}{l|l|l} 
Received: October & Accepted: October & Published: December
\end{tabular}

\begin{abstract}
Business Model Analysis and Canvas Business Model Established By The Bali Petro Jaya Company During Covid-19. The Covid-19 pandemic has an impact not only in the health sector but also in the economic sector, one of which is tourism. With the limitation of community activities, the decrease in tourist visits to Bali has forced various businesses that rely on the tourism sector to close their business activities. Bali Petro Jaya, as a gas distributor for hotels and restaurants, also felt the impact. However, these companies were able to survive with the strategies they made in accordance with the existing situation. Therefore, this study aims to determine what strategies Bali Petro Jaya used during Covid-19 using the Canvas Business Model. This study used a qualitative descriptive method using semistructured interview techniques. The result of Canvas Business Model, The company changed its business field from being originally an LPG Gas Agent with a target of hotel and restaurant consumers to become a rice distributor and selling food online to several grocery stores, rice shops, and also traditional markets after a decline in LPG sales and seeing what consumers need during the Covid-19 pandemic namely selling rice and food online. The strategy of coming directly to targeted consumers is very effective in getting new customers. This is because consumers can see examples of goods carried by the company and can also negotiate prices directly. Powering prices and using personal assistance to strengthen relationships with customers make customers feel comfortable and trust the company because a sense of kinship grows.
\end{abstract}

Keywords: Canvas Business Model, Covid-19

\section{BACKGROUND}

At the end of 2019, the world was shocked by the emergence of a new virus that was first discovered in one of the regions in China, namely Wuhan. The virus is called Coronavirus which is a group of viruses that can cause disease in animals or humans. Several types of coronavirus are known to cause respiratory tract infections in humans ranging from cold coughs to more serious ones such as Middle East Respiratory Syndrome (MERS) and Severe Acute Respiratory Syndrome (SARS) (Yuliana, 2020). This virus takes many victims, especially in humans who are elderly and have a history of the disease.

China reported the presence of this new disease on December 31, 2019, and notified it directly to the World Health Organization office in China about the presence of a type of pneumonia whose cause was unknown. The acute respiratory infection that attacks the lungs was detected in Wuhan City, Hubei Province, China. According to the authorities, some of the patients were traders operating at the Huanan Fish Market. People who have the coronavirus have common symptoms such as fever, dry cough, and feeling tired. Other less common symptoms 
that some patients may experience include aches and pains, nasal congestion, headache, conjunctivitis, sore throat, diarrhea, loss of taste or smell, rash on the skin, or discoloration of fingers or toes (Özdemir, 2020). The symptoms experienced are usually mild and appear gradually. Some people become infected but have only mild symptoms. People can catch the coronavirus from other people who are infected with this virus. The coronavirus can spread rapidly through droplets from the nose or mouth that come out when an infected person coughs, sneezes, or talks. These splashes are relatively heavy, they do not travel far and fall to the ground quickly. People can become infected with the coronavirus if they breathe in the splashes of an infected person.

These splashes can stick to objects and other surfaces around people such as tables, door handles, and handrails. People can become infected by touching these objects or surfaces, then touching their eyes, nose, or mouth. The increase in people exposed to the coronavirus in a short time made the Chinese Authorities on January 23, 2020, close down Wuhan by canceling planes and trains leaving the city, and temporarily suspending the operation of buses, subways, and ferries.

Indonesia is one of the countries that has imposed a travel ban abroad to reduce the spread of the Coronavirus (Suryadarma, 2020). This prohibition caused some airlines to cancel their flights and several airlines were forced to continue operating even though the majority of their aircraft seats were empty to fulfill passenger rights. Many consumers are delaying booking their vacation tickets because of the increasingly widespread of the Coronavirus. This situation causes the government to act by providing policies to overcome the problem. Coronavirus also has a huge impact on the tourism sector. Data from the Central Statistics Agency (BPS) shows that tourists from China reached 2.07 million people in 2019, which covered 12.8 percent of the total foreign tourists throughout 2019. The spread of the Coronavirus causes tourists to visit Indonesia to decrease. Tourism supporting sectors such as hotels, restaurants, and retail entrepreneurs were also affected by the Covid-19 pandemic. Hotel occupancy has decreased by 40 percent which has an impact on the continuity of the hotel business. The lack of tourists also has an impact on restaurants or restaurants, where most of the consumers are tourists. The weakening of tourism also has an impact on the retail industry. The areas where the retail sector is most affected are Manado, Bali, Riau Islands, Bangka Belitung, Medan, and Jakarta (Silfia et al., 2021).

The temporary closure of the operations of several hotels and restaurants cannot be avoided to maintain the company. Labor reduction must inevitably be done because most of the expenses incurred by hotels and restaurants each month come from employee salaries (Aliah, 2020). This reduction in the workforce led to an increase in the existing unemployment rate. One of the gas agents, Bali Petro Jaya, also felt the impact of the closure of hotels and restaurants.

Bali Petro Jaya is a gas supply company whose customers are hotels and restaurants that depend on visiting tourists. With the closure of hotels and restaurants, this company are biggest supplier liquid propane gas (LPG) in Bali area and also handle $60 \%$ of the gas market. They serve hotels and restaurants for gas needs. They running their business for 12 years, at the beginning Bali Petro Jaya was serve their customer especially household needs only in Denpasar, as time goes by demand not only came from house hold but also from hotels dan restaurants industry.

Currently, the world is being shaken by the Covid-19 pandemic, which has made many companies prefer to close their operations to avoid losses. So that in dealing with the impact of this pandemic, the company has implemented various strategies to maintain the company's operational activities. It is difficult for the Bali Petro Jaya company to run its business because they depend on hotels and restaurants that target tourists who come on vacation. However, companies are rapidly changing the strategies they use to survive. The sudden change in situation push them to change their business model. Innovation of business model make them create a value based on internal processes and external relation with customer and supplier (Vils et al., 2017). 
Business model has two forms, its internal constitution and its external alignment. Capability of company has over its employees gives it strength to co-ordinate their product activity (Casadesus-Masanell \& Heilbron, 2015). Objective of the analysis of business model is to deepen and broaden the awareness about fundamental component what company shoud do when they running their operational activity (Slávik \& Bednár Richard, 2014)

Canvas Business Model is a business model, a logical description of how an organization creates, delivers, and captures value (Kurniasari \& Kartikasari, 2018). With the Canvas Business Model, companies can more easily design business process plans and define and validate important business points such as; resources, activities, relationships to be established with related parties, income, and expenses that must be spent (Permana \& Yoga, 2018).

\section{LITERATURE REVIEW}

\section{Canvas Business Model}

According to (Yves Pigneur, 2018), a business model describes the rationale for how organizations create, deliver, and capture value. Business Model Generation describes how the company can provide a quick response to customer desires by providing the best values in the company. Business model generation can be reflected in the existing business model, namely the Business Model Canvas, which explains simply through the visualization displayed how the company makes money through 9 building blocks arranged into one unit. So it can be seen that the business model canvas is a business model that can describe in simple terms how an organization provides and captures the value of business activities carried out to make money. The nine (9) building blocks in the Business Model Canvas are as follows:

1. Customer Segments

The customer segment building blocks describe a group of differentpeople or organizations that the company wants to reach or serve (Yves Pigneur, 2018). Customer segments describe how a company selects the most potential customer segments to be selected so that business activities are carried out on target and following the desired target consumers (Wardhanie \& Kumalawati, 2019)

2. Value Propositions

Value proposition building blocks describe a combination of products and services that create value for specific customer segments(Yves Pigneur, 2018). Value Propositions describes how the company provides the best value to its customers following the value proposition that the company has. By creating superior customer value, the company creates customers who are very satisfied and remain loyal and are willing to buy again. This can provide benefits for the company in the future because it already has loyal customers (Simatupang \& M.Simatupang, 2013).

3. Channels

The channel building blocks describe how a company communicates with its customer segments and reaches them to provide a value proposition (Yves Pigneur, 2018). These channels explain how companies reach consumers with the communication channels, distribution used by the company (Varianto, 2017).

4. Customer Relationships

The Customer Relationship Building Blocks describe the different types of relationships companies build with specific Customer Segments (Yves Pigneur, 2018). A company must define the type of relationship it wants to build together customer segments (Tokarski et al., 2017).

5. Revenue Streams

Revenue Flow Building Block Describes the cash the company generates from each of the Customer Segments (Yves Pigneur, 2018). Revenue is an inflow or other increase in the 
assets of an entity or settlement of liabilities (or a combination of the two) during a period of delivery or production of goods, provision of services, or other activities that are the main or central operations of the entity being take place (Yulia et al., 2020).

6. Key Resources

Key resource requirements vary according to the type of business model. Microchip companies need capital intensive production facilities, while their designers are more focused on human resources. The main resources can be physical, financial, intellectual, or human. The main resources can be owned or leased by the company or acquired by the main partner (Yves Pigneur, 2018).

7. Key Activities

Key activities are needed to create and deliver value propositions, reach markets, maintain customer relationships, and generate revenue. Such as the main resource, the key activities differ depending on the type of business model (Herawati et al., 2019).

8. Key Partnerships

The main building blocks of partnership represent the network of suppliers and partners that make a business model work. Companies form partnerships for a variety of reasons, and partnerships form the basis of various business models to reduce risk or acquire their resources (Yves Pigneur, 2018).

9. Cost Structure

The Cost structure describes all the costs incurred to operate the business model. These building blocks describe the most important costs incurred when operating a particular business model (Yves Pigneur, 2018).

\section{Strategic Management}

(David, 2016) defines Strategic Management as the art and knowledge of formulating, implementing, and evaluating cross-functional decisions that help an organization achieve its goals. Based on this explanation, strategic management focuses on efforts to integrate management, marketing, finance/accounting, production, research and development, and computer information systems to achieve organizational success. The purpose of strategic management is to exploit and create new and different opportunities for the future. According to (Porter, 1985), a strategy is a tool to achieve a competitive advantage. A strategy is a shared means with long-term goals to be achieved. A strategy is a potential action that requires a large number of top management decisions and company resources. Besides, strategy influences the long-term development of the company, usually for the next five years, and is therefore oriented towards the future. In an industrial environment, suggests the concept of Competitive Strategy which analyzes business competition based on five main aspects called the Five Competing Forces or the so-called Five Forces, namely: Threats of Entering New Arrivals, Threats Industry Peer Competitors, Threats from Substitute Products or Services, Supplier Bargaining Power, and Buyer Bargaining Power. Meanwhile, the distant environment consists of Politics, Economy, Social, and Technology (PEST)(David, 2016).

\section{Target Market}

The definition of Targeting according to (Keegan \& Mark C. Green, 2008) is the process of evaluating the segmentation and focusing of marketing strategies in a country, province, or group of people who have the potential to respond. Meanwhile, according to (Kotler \& Wong, 2004), the target market is defined as a group of buyers (buyers) who have the same needs or characteristics which are the goals of company promotion. From the two definitions, it can be said that targeting is an important process in determining who will buy products from the company. (Widjaya, 2017) stated the segmentation of the target marketcan be divided into 4 types, namely:

a Undifferentiated Marketing (Mass) 
This strategi show how company ignoring the different of segmentation and give the entire market just one offer product or services.

b Differentiated Marketing (Segmented)

This strategy offering several market segment and design an offer that separately for each market segment. With various products dan marketing into the segment, company expecting the can gain sales and get the strong position in each market.

c Concentrated Marketing (Niche)

This strategy just only focusing in promote their product to the specific grup buyer, it will give more advantages to the company because they only serve one or two grup buyer.

d Micromarketing (Local or Individual Marketing)

In this strategy company just produce products to adjusting particular individual and location

\section{Research Framework}

A company has various strategies that aim to maintain and develop its business to make a profit or be number one in its class. Seeing that this year is the toughest year for the economy due to the Covid-19 pandemic, many companies are not ready to face it. As a result, some companies prefer to close their operational activities because there are no other strategies that must be taken to save their companies. Behind the closure of several companies' operational activities, one of the companies acting as an LPG gas agent, Bali Petro Jaya, continues to run its business with several strategies that have been prepared to defend their business from losses caused by this pandemic. With this strategy, a Business Canvas Model was created which aims to help companies design business process plans and define and validate important points in business such as; resources, activities, relationships to be established with related parties, income, and expenses that must be incurred.

Table 1 Research Framework

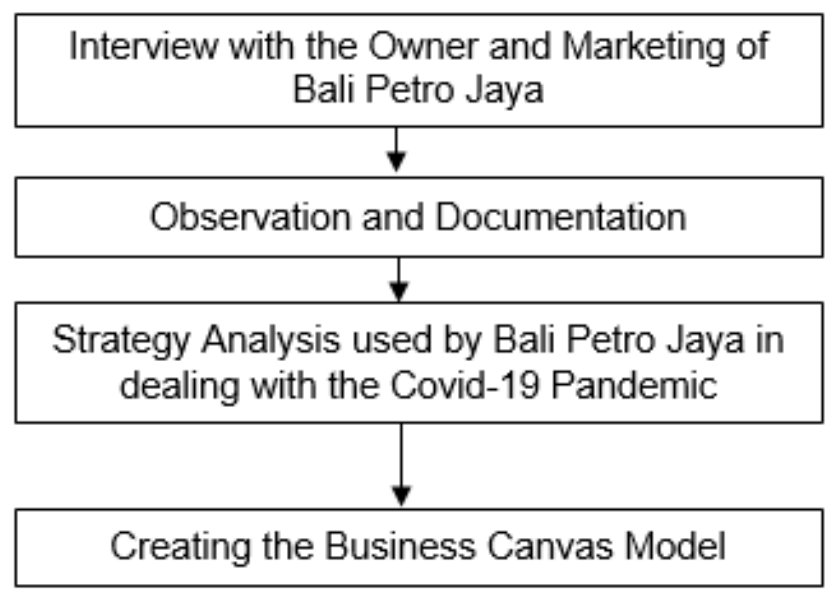

RESEARCH METHODOLOGY

This research was conducted in Bali Petro Jaya, which is located on Jalan Gumuh Ayu X, Darmasaba, Badung, Bali. This research was conducted to obtain data related to the problems to be studied. The main reason for conducting this research is because Bali Petro Jaya is one of the LPG gas agents that was established in 2009 and is currently surviving and continues to develop and improve. 
The type of research used is based on the approach and type of research used, this research is included in qualitative research. Bogdan and Taylor (in Moleong, 2006) define a qualitative method as a research procedure that produces descriptive data in the form of oral written words from people and observable behavior. Qualitative research will produce descriptive data in the form of words. The data were analyzed in descriptive form and not in the form of numbers as in quantitative research (Sugiono, 2009). According to (Moleong, 2009), descriptive research emphasizes data in the form of words and pictures, not numbers caused by the application of qualitative methods. Besides, everything that is accumulated will likely be the key to what was.

This research uses purposive sampling, namely by selecting samples based on research needs and the informants is a party from the company who understands the condition of the Bali Petro Jaya company under study, so the researcher decided to interview the informant, the owner, and the marketing of the Bali Petro Jaya company To make it easier to define the informans, they will given the code as follows "informant A" for owner of Bali Petro Jaya company and "informant $B$ for marketer of the Bali Petro Jaya company.

Data collection methods used in this study include observation and interview methods. To check the validity of the data in this study, researchers used a triangulation technique. According to (Sugiono, 2009) triangulation is defined as a data collection technique that combines data from various data collection techniques and existing data sources.

\section{RESULTS AND DISCUSSION}

Bali Petro Jaya was established in Tabanan Regency, Bali in 2009 at the same time the kerosene to LPG conversion program was rolled out in this area.Initially, the company's goal was to play a role in the success of the kerosene to LPG conversion program. So later we can promote the use of ELPIJI as a source of meeting the main domestic energy needs and are environmentally friendly because we are also committed to always preserving nature and the environment as a trust for our future generations. Starting from dominating the Small and Medium Enterprises market segment, Bali Petro Jaya continues to develop and penetrate industrial sectors that support the tourism industry such as leading hotels and restaurants in Bali.

However, since the Covid-19 pandemic, the sales of LPG gas in Bali Petro Jaya have decreased significantly. Coupled with the closure of hotels and restaurants due to the absence of tourists due to Covid-19, it is difficult for companies to carry out their business activities. Because of this, companies that made strategic changes to survive this pandemic and the strategies they implemented turned out to be successful in enabling the Bali Petro Jaya company to cover its operational costs.

\section{Switching Strategies}

First interview was focus on the strategies used in Bali Petro Jaya during this pandemic COVID-19. In an interview with informant A explained that:

"The company experienced a decline in revenue due to the closure of restaurants and hotels, which are customers from Bali Petro Jaya. The first strategy, the company tries to reduce the burden borne by the company, for example reducing employees. Also, debt restructuring by participating in relaxation to get relief from the bank even though in reality we still pay normally because we can survive by diverting our business to another field, namely selling rice because I think human needs must eat so from there finally there is an idea to sell. rice. Besides, the company also sells food online but cannot cover it because sales are still small, while rice sales can support the company to help finance operations and pay bank installments". 
Informant $\mathrm{B}$ also gave the same statement that the company reduced its operational costs by reducing employees and also switched to other businesses, namely rice sales due to the decline in LPG sales due to Covid-19.

"When there was a decline in sales, the company began to feel like trying to change the payment system to cash paid on the spot, no longer monthly to prevent payment stagnation. For employee's expenses, it is also reduced to reduce the burden of operating costs from the company. As gas sales continued to decline over time, we form the company tried to shift our business to selling rice and the results could help the company survive."

By shifting the business sector from selling LPG gas to rice, the marketing strategy must be changed. Following what with informant $A$ explained, to get new customers, the company visits wholesalers, rice shops, and markets directly as well as providing samples of goods being sold and also negotiating prices directly on the spot. This marketing strategy makes it faster for the company to market rice, increase sales, and also get new customers.

"The company targets wholesalers, rice shops, and markets by coming directly to the targeted consumers and providing samples of the rice we sell and the price. If he gets more expensive, we give him a little down so he wants to move, if he wants to look for it, he'll be happy because he wants to try later there could be a possibility of repeat orders. The point is, as long as we go to see the rice shop, we will stop while also if there is a restaurant open we will go to the gas business so that it can run. You could say the strategy is door to door in marketing this rice. I think that if only the proposal is written it's not effective, wait for the news for a long time so it's better to meet face to face with consumers. From online, at the beginning of the pandemic, we continued to post on Instagram and fan pages. Not bad, some can order, but it's not continuous, just once for help. Most of the repeat orders come from shops and markets that we go directly to. As for gas, we keep the strategy through Instagram and Facebook fan page and on Google we create Google My Businesses so that our company is on Google."

According to Informant B , it is certain that the company must change its marketing strategy by adjusting to new business fields to get customers. The use of social media as a place to market rice was also carried out but it was deemed ineffective. She believes that the door-todoor strategy of meeting customers in person is very effective because she can find out what consumers need quickly.

"It is said that the effect is certain, especially in this pandemic, no one expected that it would end up like this. Like it or not, the company has to change its marketing strategy while looking at the existing situation. From what I see effective because we know better what consumers need faster. It is even more troublesome, it seems that it is a quick way to increase rice sales which can make the companv meet the costs it has to spend every month. Rather thar process too Creating Canve

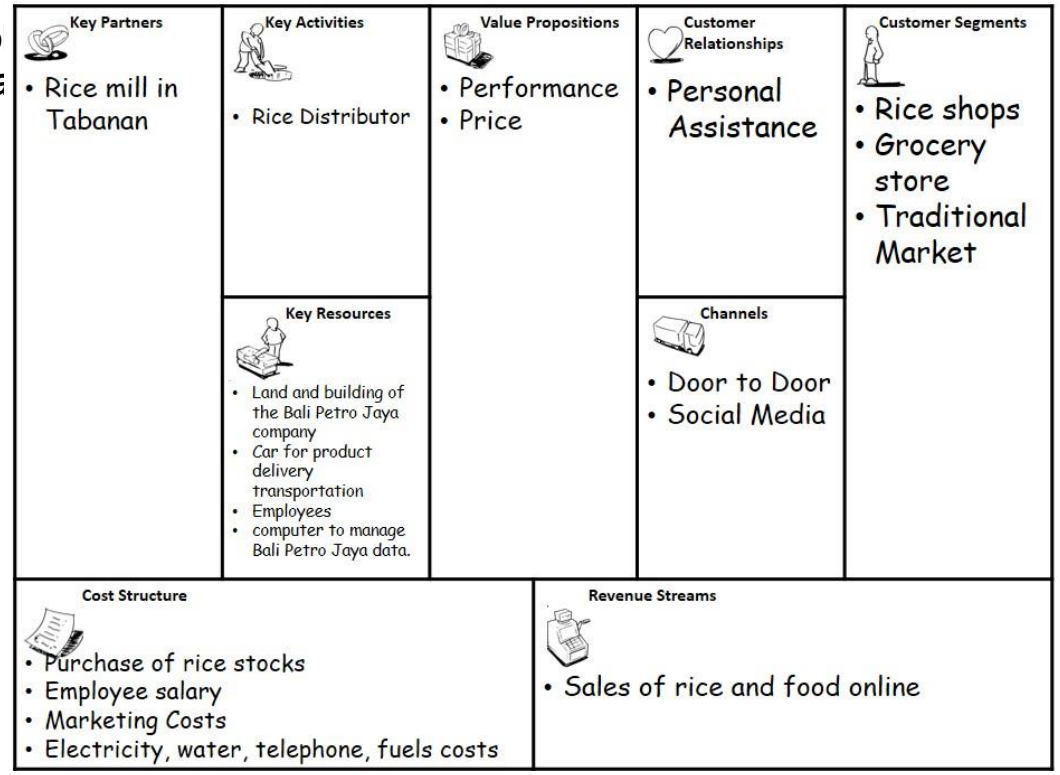
iffective and the 
Based on the results of previous interviews, several important strategies were obtained that helped the Bali Petro Jaya company survive the Covid-19 pandemic, which will then create a Canvas Business Model regarding the important strategies used.

1. Customer Segments

Customers from Bali Petro Jaya are hotels and restaurants, but due to the decline in gas sales due to the Covid-19 pandemic, customers from Bali Petro Jaya have turned into wholesalers, rice shops, and markets. The selection of wholesalers, rice shops, and markets is because the company does not have shops on the roadside or in markets. If a company wants to open its shop or rent a shop, it requires a large number of funds while the company has little funds. With the lack of funds available, the company prefers to sell as a distributor by supplying rice to wholesalers, shops, or markets while optimizing resources in the form of vehicles that are currently unemployed which previously were used to deliver LPG gas to hotels and restaurants.

2. Value Propositions

In the performance element, the company provides value in the form of services provided to customers. What is meant here is how the behavior or treatment is given by the company during the service process to customers. The company provides maximum service to customers by coming directly to them and bringing samples of goods being sold as well as negotiating the desired price directly at the customer's place. It aims to increase customers' trust and comfort in the company and create a close family relationship between the customer and the company. Also, customers do not feel confused because there are no samples of goods provided and the negotiation process is more effective and efficient than the customer having to read the proposal and then negotiate over the phone which makes the customer feel uncomfortable.

Price is one of the things that affect customer interest because if the price sold is higher than other competitors, the customer will not want to move to Bali Petro Jaya. The price offered by Bali Petro Jaya itself is adjusted to the quality of the product it owns. Bali Petro Jaya has an alternative strategy that encourages customers to move, namely by providing a slightly cheaper price. This price reduction is intended so that customers are willing to divert purchases to the company rather than its competitors so that the company can increase their sales if many customers switch to Bali Petro Jaya.

3. Channels

Bali Petro Jaya gets customers by door to door, which way directly meets the target customers to be targeted. In this way, the company can provide samples of goods as well as negotiate prices on the spot. This door-to-door application is very effective because customers do not need a long time to negotiate and for companies, this strategy is the fastest way to get customers and also increase sales.

4. Customer Relationship

To foster good relationships with customers, the company uses a personal assistance strategy in which the company directly interacts with customers. The person who intervenes directly from the company is the owner of the company. The owner has a goal to strengthen the relationship with customers more than just signing a work contract or through employees, so it is more family-friendly. With the direct reduction of the Owner in interacting with customers, it makes customers feel comfortable and becomes more flexible if they want to negotiate prices and avoid fraud committed by company employees.

5. Revenue Stream

The revenue streams that companies received during the Covid-19 pandemic came mostly from rice in the form of recurring revenues. This recurring income is because rice has a useful life before deteriorating in quality and must be purchased 
continuously. Due to the decline in LPG sales, the largest company revenue is obtained from the sale of rice that is offered and sold by the company to wholesalers, shops, and markets.

6. Key Resource

Physical resources owned by Bali Petro Jaya are land and buildings from Bali Petro Jaya, employees who work in the company, cars for product delivery transportation, and also computers to manage Bali Petro Jaya data.

7. Key Activities

The company's main activity is currently a rice distributor before Covid-19 Bali Petro Jaya only focused on being an LPG gas agent. As a rice distributor, the company distributes rice to rice shops, wholesalers to markets. The company chose to become a rice distributor due to observations of the current situation in which even people who have no income must still fulfill their needs for food or their primary needs (autonomous consumption). Rice is also a staple food for people in Indonesia. Besides, because it chooses as a distributor, the company must focus on one type of product being sold to optimize the remaining capital it has so that it can buy products in relatively larger quantities. So, with the increasing number of purchases, it will affect the cheaper the price that is obtained when purchasing goods.

8. Key Partnership

Bali Petro Jaya collaborates with the required suppliers. The existence of cooperation with several suppliers can reduce the risk of shortages of stock of goods. The supplier that is currently working with Bali Petro Jaya is the Rice Mill in Tabanan. The choice of Rice Mill in Tabanan as a place to buy rice is because Tabanan is a rice barn and also has the largest number of rice mills in Bali. Besides, the company also imported rice directly from outside Bali, namely Lombok and Java. The supply of rice from outside Bali is heavily influenced by prices. This is because if the areas outside Bali are in high harvest, the price of rice tends to be cheaper and this is very possible for rice from outside Bali to enter and compete with local rice in Bali.

9. Cost Structure

The Bali Petro Jaya company focuses on structuring its costs on a cost-driven basis. Furthermore, a cost-driven focuses on the company's efforts as much as possible to minimize costs incurred. Costs that do not need to be incurred so that these costs can be transferred to other capital. The costs incurred by the company are fixed costs and variable costs. Fixed costs at Bali Petro Jaya include employee salaries, electricity, telephone, and water costs. Meanwhile, variable costs include promotional costs, transportation fuel, and advertising on social media.

The savings that Bali Petro Jaya has made are reducing the number of employees and if rice orders increase, the company relies on daily workers. That way the fixed costs incurred are reduced.

\section{CONCLUSIONS}

Based on the results of the discussion in this study, several conclusions can be presented as follows. The new strategies produced during the pandemic based on interviews with Bali Petro Jaya are as follows ; The company changed its business model from being originally an LPG Gas Agent with a target of hotel and restaurant to become a rice distributor and selling food online to several grocery stores, rice shops, and also traditional markets after a decline in LPG sales and seeing what consumers need during pandemic COVID-19, The strategy of coming directly to targeted consumers is very effective in getting new customers. This is because consumers can see examples of goods carried by the company and can also negotiate prices directly. Canvas 
business model one of business model that builds it components separately, In future research, can be added $360^{\circ}$ business model to make it more integrated.

\section{REFERENCES}

Aliah, N. (2020). The Impact of Covid-19 On National Economic Growth.

Casadesus-Masanell, R., \& Heilbron, J. (2015). Business Models Nature and Benefits. SSRN Electronic Journal. https://doi.org/10.2139/ssrn.2606692

David, F. R. (2016). Strategic Management.

Herawati, N., Lindriati, T., \& Suryaningrat, I. B. (2019). Penerapan Bisnis Model Kanvas Dalam Penentuan Rencana Manajemen Usaha Kedelai Edamame Goreng. Jurnal Agroteknologi, 13(01), 42. https://doi.org/10.19184/j-agt.v13i01.8554

Keegan, W. J., \& Mark C. Green. (2008). Global Marketing.

Kotler, P., \& Wong, V. (2004). Principles of Marketing.

Kurniasari, R., \& Kartikasari, D. (2018). Penerapan Model Bisnis Kanvas Terhadap Bisnis Jasa Angkut Penumpang Pada PT Internasional Golden Shipping.

Moleong, L. J. (2009). Metodologi Penelitian Kualitatif.

Özdemir, Ö. (2020). Coronavirus Disease 2019 ( COVID-19): Diagnosis and Management. 42(3), 242-247. https://doi.org/10.14744/etd.2020.99836

Permana, G. P. L., \& Yoga, I. M. S. (2018). ADAPTASIMODEL BISNIS UNIQLO DENGAN MENGADOPSI CANVAS BUSINESS MODEL DAN 360॰BUSINESS MODEL.

Porter, M. E. (1985). Competitive Strategy.

Silfia, B., Utami, A., \& Kafabih, A. (2021). SEKTOR PARIWISATA INDONESIA DI TENGAH PANDEMI COVID 19. 4(1), 383-389.

Simatupang, L., \& M.Simatupang, T. (2013). CONSTRUCTING SOCIAL VALUE NAVIGATION MODEL TO COMPLEMENT A SOCIAL ORGANIZATION'S STRATEGY DEVELOPMENT FRAMEWORK. 2(6), 710-725.

Slávik, Š., \& Bednár Richard. (2014). Analysis of Business Models. Journal of Competitiveness, 6(4), 19-40. https://doi.org/10.7441/joc.2014.04.02

Sugiono. (2009). Metode Penelitian Kuantitatif, Kualitatif dan R\&D (p. 96).

Suryadarma, D. (2020). The Impact of COVID-19 Outbreak on Poverty : An Estimation for Indonesia.

Tokarski, A., Tokarski, M., \& Wójcik, J. (2017). The Possibility Of Using The Business Model Canvas In The Establishment Of An Operator' S Business Plan. Torun Business Review, 16(4), 17-31. https://doi.org/10.19197/tbr.v16i4.117

Varianto, V. (2017). Model Bisnis Colleges Need Menggunakan Pendekatan Business Model Canvas. Jurnal Manajemen Dan Start-Up Bisnis, 2(3), 351-358.

Vils, L., Mazzieri, M. R., Rodrigues, G. V., Da Silva, A. R., \& Queiroz, M. J. de. (2017). Business Model Innovation: A Bibliometric Review. International Journal of Innovation, 5(3), 311324. https://doi.org/10.5585/iji.v5i3.243

Wardhanie, A. P., \& Kumalawati, D. (2019). Analisis business model canvas pada perpustakaan Institut Bisnis dan Informatika Stikom Surabaya dalam meningkatkan kualitas perguruan tinggi. 1, 105-112.

Widjaya, P. G. (2017). Analisis Segmenting, Targeting, Positioning dan Marketing Mix pada PT Murni Jaya. Agora, 5(1), 12. http://publication.petra.ac.id/index.php/manajemenbisnis/article/view/5307/4889

Yulia, Y., Bahtera, N. I., Evahelda, E., Hayati, L., \& Bahtera, N. T. (2020). Business Development Strategy Using Business Model Canvas Approach. Jurnal Muara IImu Ekonomi Dan Bisnis, 4(1), 106. https://doi.org/10.24912/jmieb.v4i1.7563

Yuliana. (2020). Corona virus diseases (Covid-19); Sebuah tinjauan literatur. 2(February), 187- 
192.

Yves Pigneur, A. O. (2018). Business Model Generation ( Alexander Osterwalder \& Yves Pigneur ). 1-9. 